\title{
Protection and Management Policy on Angkor Wat Temple in Cambodia: An Overview
}

\author{
Rathny Suy ${ }^{1}$--- Leaksmy Chhay ${ }^{2}$--- Chakriya Choun ${ }^{3}$

 \\ Email:rathny@mail.ustc.edu.cn \\ ${ }^{2}$ School of Management, University of Science and Technology of China, Hefei, Anhui, 230026, China. \\ ${ }^{3}$ School of Public Administration, Central South University, Changsha, Hunan, China.
}

\begin{abstract}
This paper described on protection and management of the Cambodian government on the Angkor Wat temple. It also expressed to the Angkor Wat during the Pol Pot regime that is the zero time, the country had destroyed almost sectors, and Angkor was closed during that time, and some parts of Angkor Wat were destroyed. By the late Cambodian King Norodom Sihanouk, Angkor Wat was listed in UNESCO's World Heritage in Danger (later removed in 2004), because he submitted a request for help in 1992. To protection from the Angkor Wat site, World Heritage Site together with an appeal by UNESCO to the international community to rescue Angkor in 1994. In 1995, APSARA was established to protect and manage the area, and a law to protect Cambodian heritage was released in 1996. This review paper aims to provide the brief history of Angkor Wat temple as well.
\end{abstract}

Keywords: Protection Policy, Management Policy, Angkor Wat temple, Cambodia.

Licensed: This work is licensed under a Creative Commons Attribution 4.0 License.

\section{Introduction}

Cambodia represents an ancient country in Asia. Cambodia is the Kingdom of Wonder, which has had a high old-time civilization, in particular during the Angkor Era; Cambodian ancestors had constructed thousands of temples and are always existed. These constructions reflect the culturally rich and abundant. Angkor is part of the most important archaeological sites in South-East Asia. For an instant, Cambodia has Angkor Wat Temple, Bayon Temple in Siem Reap province, Preah Vihea Temple in Preah Vihea province, and thousand other temples throughout the country (Nguon, 2010).

From the 9th to the 15th century, including forested area, Angkor Archaeological Park includes the magnificent remains of the different capitals of the Khmer Empire had stretched over some $400 \mathrm{~km} 2$. They contain the famous Temple of Angkor Wat and, at Angkor Thom, the Bayon Temple with its countless sculptural decorations (KHMER TIME, 2017; Wikivoyage, 2018). UNESCO has set up a wide-ranging program to safeguard this symbolic site and its surroundings (UNESCO, 1992). Indian architecture and some details from Cham and Javanese styles were influenced a definite on Angkor. As the capital cities of the empire were being built around the temples, an elaborate irrigation system consisting of canals, moats and reservoirs was created for both agricultural and religious purpose (UNESCO, 2013). Angkor Wat temple is the soul of Cambodia, that why the government takes action to protect this site with prudent management.

Angkor Wat has reached to over 1.23 million visitors during the first half of 2015 with revenues of 35 million US dollars (APSARA, 2015). This excessive overcrowding could be a possibility threat to the ancient monument. Tourism stands for a tremendous economic potential but it can also generate irreparable destruction of the tangible as well as intangible cultural heritage as stated in the Convention concerning the Protection of the World Cultural and Natural Heritage (UNESCO, 2012). 
Regarding to this concern, an International Coordinating Committee for the Safeguarding and Development of the historic site of Angkor (ICC-Angkor) was established in order to ensure the coordination of successive scientific, restoration and conservation-related projects in 1993. Moreover, a wide-range of programs was established by UNESCO to protect this symbolic site and its surroundings, which are already legally safeguarded by a number of laws and policies (Seth, Chea, Fisher and Chea, 2015).

The Cambodian government complied a strategy to divert visitors to other touristy destinations in the country with a range of impressive temple sites, eco-adventure holidays, and newly developed beach resorts to prevent further destruction to the Angkor World Heritage site (World Archaeology, 2015). This review paper is designed to describe about history of Angkor Wat temple in Cambodia. It also aims to provide the protection and management policy on Angkor Wat temple in Cambodia.

\subsection{Angkor Wat Temple: Brief History}

Angkor is the architecture and layout of the successive capitals is a testament to a high level of social order and ranking within the Khmer Empire. It also is a great site exemplifying cultural, religious and symbolic values, as well as containing high architectural, archaeological and artistic significance. The site integrity however, is put under dual pressures: 1) endogenous: exerted by more than 100,000 inhabitants distributed over 112 historic settlements scattered over the site, who constantly try to expand their dwelling areas; and 2) exogenous: related to the proximity of the town of Siem Reap, the seat of the province and a tourism hub (UNESCO, 1992).

When the Khmer Rouge took over in 1975, they went to temples and destroyed all the statues, mostly by beheading them and hiding or scattering them in the jungle. Because of the genocide of the Khmer Rouge, Cambodia is missing almost an entire generation and more than that its missing the population with any skills or education, and the Angkor Wat was closed during that time, and some parts of Angkor Wat were destroyed (Wikipedia, 2018).

In 1908, the restoration of Angkor Wat in the modern era started with the creation of the Conservation d'Angkor (Angkor Conservancy) by the École française d'Extrême-Orient (EFEO). Before that date, the activities at the site were primarily concerned with exploration; and the Conservation d'Angkor was in charge of the research, conservation, and restoration activities carried out at Angkor until the early 1970s (APSARA, 1995; Wikipedia, 2018). In addition, protection from Angkor was gone up during the Khmer Rouge era and the Conservation d'Angkor was disbanded in 1975. Between 1986 and 1992, the Archaeological Survey of India carried out restoration work on the temple, as France did not recognize the Cambodian government as the time (Kapila and Neel, 2013).

In 1992, following a request for assist by late Cambodian King Norodom Sihanouk, Angkor Wat was listed in UNESCO's World Heritage in Danger (later removed in 2004) and World Heritage Site together with an appeal by UNESCO to the international community to safeguard Angkor, and the Zoning of the area was set up to protect the Angkor site in 1994, APSARA was established in 1995 to protect and manage the area, and a law to protect Cambodian heritage was released in 1996 (Falser, 2015). A number of countries such as France, Japan, and China are involved in various Angkor Wat conservation projects.

\subsection{Protection and Management Policy}

On $28^{\text {th }}$ May 1994, the property which is legally protected by the Royal Decree on the zoning of the Region of Angkor (Siem Reap Province) was adopted. The law on the protection of natural and cultural heritage was promulgated on 25 January 1996. On $19^{\text {th }}$ February 1995, the Royal Decree on the creation of the APSARA National Authority (Authority for the protection of the site and the management of the Angkor Region) was laid down. The No. 70 SSR government Decision, dated 16 September 2004 providing for landuse in the Angkor Park: "All lands located in zone 1 and 2 of the Angkor site are State properties", and the sub-decree No. 50 ANK/BK on the organization and functioning of the APSARA National Authority adopted on $9^{\text {th }}$ May 2008, specifically provided for the establishment of a Department of Land-use and Habitat Management in the Angkor Park (Seth et al., 2015).

The national cultural heritage comprises cultural property created or discovered on federal territory. The purpose of this law is to protect national cultural heritage and cultural property in general against illegal destruction, modification, alteration, excavation, alienation, exportation or importation. This law shall apply to movable and immovable cultural property, whether publicly or privately owned, whose protection is in the public interest (RGC, 1996).

The successful conservation of the property by the APSARA National Authority, monitored by the ICCAngkor, was crowned by the removal of the property from the World Heritage List in danger in 2004.

Angkor is one of the largest archaeological sites in operation in the world. The anthropological studies on socio-economic conditions) result in a better knowledge and understanding of the history of the site, and its inhabitants that constitute a rich exceptional legacy of the intangible heritage (UNESCO, 1992; Wikipedia, 2018). The purpose is to associate the "intangible culture" to the enhancement of the monuments in order to sensitize the local population to the importance and necessity of its protection and preservation and assist in the development of the site as Angkor is a living heritage site where Khmer people in general, but especially 
the local population, are known to be particularly conservative with respect to ancestral traditions and where they adhere to a great number of archaic cultural practices that have disappeared elsewhere.

Moreover, the Angkor Archaeological Park is very rich in medicinal plants, used by the local population for treatment of diseases. The plants are prepared and then brought to different temple sites for blessing by the gods. These aspects of intangible heritage are further enriched by the traditional textile and basket weaving practices and palm sugar production, which all result in products that are being sold on local markets and to the tourists, thus contributing to the sustainable development and livelihood of the population living in and around the World Heritage site (Wikipedia, 2018; Wikivoyage, 2018).

The Public Investigation Unit was established to identify visitors' demands and expectations, and to oversee the visitors' behaviours, so that particular policies and management could respond to these issues. Intangible cultural heritage has been associated with tangible heritage, specifically Angkor Wat, to protect the local population living within the development site, and to help them maintain their ancestral traditions and cultural practices (UNESCO, 2012).

The management of the Angkor Site, which is inhabited, also takes into consideration the population living in the property by associating them to the tourist economic growth in order to strive for sustainable development and poverty reduction.

Two major contributions supporting the APSARA National Authority in this matter are:

1. The Angkor Management Plan (AMP) and Community Development Participation Project (CDPP), a bilateral cooperation with the Government of New Zealand. The AMP helps the APSARA National Authority to reorganize and strengthen the institutional aspects, and the CDPP prepares the land use map with an experimental participation of the communities and supports small projects related to tourist development in order to improve the income of villagers living in the protected zones;

2. The Heritage Management Framework composed of a Tourism Management Plan and a Risk map on monuments and natural resources; a multilateral cooperation with the Government of Australia and UNESCO. Preliminary analytical and planning work for the management strategy will take into account the necessity to preserve the special atmosphere of Angkor. All decisions must guarantee physical, spiritual, and emotional accessibility to the site for the visitors (Seth et al., 2015; UNESCO, 2017).

One of the most promising strategies to protect the cultural heritage has been the growing number of Cambodian homestay schemes that have been initiated to provide tourists with a meaningful and unique experience because they will be able to stay with the local population and understand more clearly about the Khmer culture and lifestyles.

\section{Conclusion}

The excessive overcrowding at this site has brought some irreversible and irreparable destruction However, there are a number of policies and laws in place to provide protection and allow economic development following the creation of the International Coordinating Committee for the Safeguarding and Development of the historic site of Angkor (ICC-Angkor) in 1993. In order to prevent such illicit activities taking place in the future, countries need to work collectively through: the establishment task force with an Advisory Council to overlook the work at regional and international level to combat cultural racketeering; and finally, the establishment of an independent centre to combat antiquities laundering are some of the essential action plans to prevent any further cultural damage in the future.

\section{Acknowledgments}

The authors would like to thank the anonymous reviewers and the academic editor of this journal for the invaluable comments and suggestions which have substantially improved the manuscript.

\section{References}

APSARA, (1995). The modern period: The creation of the Angkor conservation. Phnom Penh, Cambodia: APSARA Authority, the Ministry of Tourism. pp: 5

APSARA, (2015). APSARA authority: Number of foreign tourists to angkor increases slightly in first seven months. Available from: http://www.cambodiatips.com/news/19153/apsaraauthority:-number-offoreign-tourists-to-angkor-increases-slightly-in-first-seven-months.html.

Falser, M. (2015). Cultural heritage as civilizing mission. Switzerland: Springer International.

Nguon, N. (2010). Protecting and respecting cultural diversity in Asia. Phnom Penh, Cambodia: Asian Parliamentary Assembly. pp: 6

Kapila, D. S. \& Neel, K. C. (2013). Asian heritage management: Contexts, concerns, and prospects. UK: Routledge.

KHMER TIME, (2017). Angkor Wat crowned the best UNESCO world heritage site. Available from: http://www.khmertimeskh.com/5093520/angkor-wat-crowned-the-best-unesco-world-heritagesite/. 
RGC, (1996). Cambodian KRAM: The protection of cultural heritage. Phnom Penh, Cambodia: Royal Government of Cambodia. pp: 12.

Seth, S., Chea, M., Fisher, R. \& Chea, S. (2015). Ensuring lasting protection against the destruction and deterioration of tangible and intangible cultural heritage of humanity. Phnom Penh, Cambodia: Parliamentary Institute of Cambodia. pp: 10.

UNESCO, (1992). Angkor Wat in Cambodia. Available from: http://whc.unesco.org/en/list/668

UNESCO, (2012). Convention concerning the protection of the world cultural and natural heritage. Paris: World Heritage Committee; United Nations Educational, Scientific and Cultural Organization. pp: 150 .

UNESCO, (2013). The program for safeguarding of Angkor. Available from: http://www.unesco.org/new/en/phnompenh/culture/tangible-heritage/icc-angkor/theprogramme-forthe-safeguarding-of-angkor/.

UNESCO, (2017). Intangible heritage Phnom Penh. Cambodia: UNESCO Office in Phnom Penh.

Wikipedia, (2018). Angkor Wat. Available from: https://en.wikipedia.org/w/index.php?title=Angkor_Wat\&oldid=826944611.

Wikivoyage, $\quad$ C. (2018). Angkor $\quad$ archaeological park. Available from: https://en.wikivoyage.org/w/index.php? title=Angkor_Archaeological_Park\&oldid=3411650.

World Archaeology, (2015). Angkor Wat: Temple of boom. Available from: http://www.worldarchaeology.com/features/angkor-wat-temple-of-boom.htm. 